\title{
MINIMIZE ENERGY REQUIRMENETE FOR HEATING BROILER HOSUING
}

\section{Fouda, T.Z* , M. R.,Darwesh ${ }^{* *}$ and M. S.,Ghoname ${ }^{* * *}$}

\begin{abstract}
The main objective in brooding is to efficiently and economically provide a comfortable, healthy environment for growing birds. Bird's age is a governor factor to determine the heating load for broiler housing particularly during winter season. Forced air heating system should be put the broiler in thermal comfortable zone to obtain the higher production. Therefore, using perforated polyethylene duct to improve this heating system may cause better thermal conditions inside the broiler housing by reducing the temperature stratifications. So that the experiment was conducted out in private broiler house during winter season of 2011, under the climatic conditions of middle area of coastal Delta, Egypt (latitude and longitude angles are $30.67^{\circ} \mathrm{N}$ and $30.98^{\circ} \mathrm{E}$, respectively). The obtained results showed that using perforated polyethylene duct increases the indoor air temperature throughout the bird's life, resulting in saved gas consumption by $32.6 \%$, reduced litter moisture content from 41.5 to $32.8 \%$, reduced supplementary heat from 45.72 to $32.4 \mathrm{kWh}$ and increased feed conversion efficiency from 60.4 to 62.2 at the end of birds life.
\end{abstract}

\section{INTRODUCUTION}

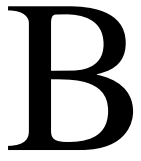
roiler production industry is one of the most important sources that can be produced cheap protein. They have a higher marketable competition ability comparing with other sources of protein such as beef, buffalo, cheap and goat, because their high feed efficiency and short period of capital cycle. In Egypt the total numbers of active broiler houses was 21,218 houses in 2008, with total complement of 34.229 million broilers (Egyptian Ministry of Agriculture, 2009).

${ }^{*}$ Prof. of Agric. Eng. Dept., Fac. of Ag., Tanta .Univ.

${ }^{* *}$ Lecturer in Agric. Eng. Dept., Fac. of Ag., Tanta .Univ.

${ }^{* * *}$ Assistant lecturer in Agric. Eng. Dept., Fac. of Ag., Tanta .Univ. 
Air temperature and its quality, relative humidity and light are critical factors to consider. Failure to provide the adequate environment during the brooding and growing periods will reduce profitability, resulting in reduced growth and development, poorer feed conversion, and increased disease, condemnation and mortality. The dominant source of heat is the birds themselves, and as a slaughter weight of $2 \mathrm{~kg}$ is approached about 10-15 Watts of heat (Mitchell and Kettewell, 1998).

Brooding (from day-old to 3 weeks), the normal pattern of brooding chicks is to warm them in a confined area at approximately $35^{\circ} \mathrm{C}$ at dayold and then subsequently reduce this by $0.5^{\circ} \mathrm{C}$ daily. From the age of 3 weeks onwards, further reductions in temperature are justified. In the case of broilers the air temperature should be of the order of $18-21^{\circ} \mathrm{C}$ with a definite tendency to the upper limit if there is any danger of the temperature dropping below $18^{\circ} \mathrm{C}$ owing to the outdoor conditions (Lacy, 2002; Fairchild, 2009).

Donald (2003) reported that, the ventilation system should exhaust the right amount of air from brooder house to maintain proper air quality and not waste energy, so the minimum ventilation rate should be increased from $0.17 \mathrm{~m}^{3} / \mathrm{h}$ for each bird in the first week to $1.36 \mathrm{~m}^{3} / \mathrm{h}$ for each bird over 8 weeks.

Fairchild (2012) reported that, brooded chicks at starting temperatures of $34,32,28$ and $26^{\circ} \mathrm{C}$, then decreased brooding temperatures by 2 to $3^{\circ} \mathrm{C}$ each week for the first fourth weeks. After brooding period temperatures are held constant at $21^{\circ} \mathrm{C}$. This range of temperature for brooding period weight and feed conversion are better for the chicks brooded at the warmer temperatures. He also recommended that a low level of air relative humidity should be maintained between 50 and $70 \%$ throughout the grow out period, including the brooding period.

Ghoname (2012) used two different surface areas in brooding stages by partitioning barn with curtains. He employed $187.5 \mathrm{~m}^{2}$ of the house for the first ten days of the chick's life to regulate their metabolic processes in order to adequately control their body temperatures. After first brooding period, this area increased to $352.2 \mathrm{~m}^{2}$. This applied in floor surface area mean that one-fourth of the space market sized broilers and one-half of it used throughout heating in the first and second two weeks, 
respectively. This strategy saving about $40-45 \%$ in supplementary heating fuel energy consumed. The indoor air temperature according to the age is the most important environmental factor. As it is well known that is a thermo-neutral (comfort) zone for first term of breeding process. Therefore, an environmental control system may be needed to provide and maintain the required comfort zone within broiler housing. From the viewpoint of thermal factors, an environmental control system may be used as an auxiliary system to control the temperature within the comfort zone via heating process.

The forced air furnace is one of the common ways that can be used to heat the indoor air around broiler chickens. Nevertheless, when used a forced air furnace a temperature stratification phenomena may occur when the source of heat energy supply inside the poultry housing is installed on the middle vertical height of the house. With this location, most of warm air moves upward to the ceiling zoon and not downward to floor surface. Therefore, it is imperative to minimize this phenomenon inside the broiler housing particularly during the heating cycle (Czarick and Fairchild 2003; and Fairchild, 2005).

\section{The main objectives of this study are to:}

(1) Provide better thermal environment, (2) Reduce heating energy consumption, and (3) maximize meat production.

\section{MATERIALS AND METHODS}

The experimental work was carried out in private commercial broiler house, located at Babel, Menofia Governorate (latitude and longitude angles of $30.67^{\circ} \mathrm{N}$ and $30.98^{\circ} \mathrm{E}$, respectively). The geometric characteristics of the commercial broiler house are as follows; total length, $35 \mathrm{~m}$, width, $15 \mathrm{~m}$, height, $3.1 \mathrm{~m}$, floor surface area, $525 \mathrm{~m}^{2}$, and house volume, $1627.5 \mathrm{~m}^{3}$. It was orientated with East-West direction. The ceiling and floor are constructed of $15 \mathrm{~cm}$ reinforced concrete, and the house side walls are built of $10 \mathrm{~cm}$ red bricks with mortar of cement and sand and coated of $5 \mathrm{~cm}$ mortar of cement and sand from inside and outside.

\section{Heating air system}

To provide and maintain an adequate amount of heat energy within the broiler house, a forced air furnace (E 120 BABYSER) as shown in Fig. 1 
was functioned during the heating period of experimental work (winter season of 2011). The forced air furnace consists of (furnace, counter flow heat exchanger, axial fan $75 \mathrm{~cm}$ taken its motion directly from electric motor 3 phase with $1.5 \mathrm{kWh}$ in power). The air fan capacity is 11,000 $\mathrm{m}^{3} / \mathrm{h}$.

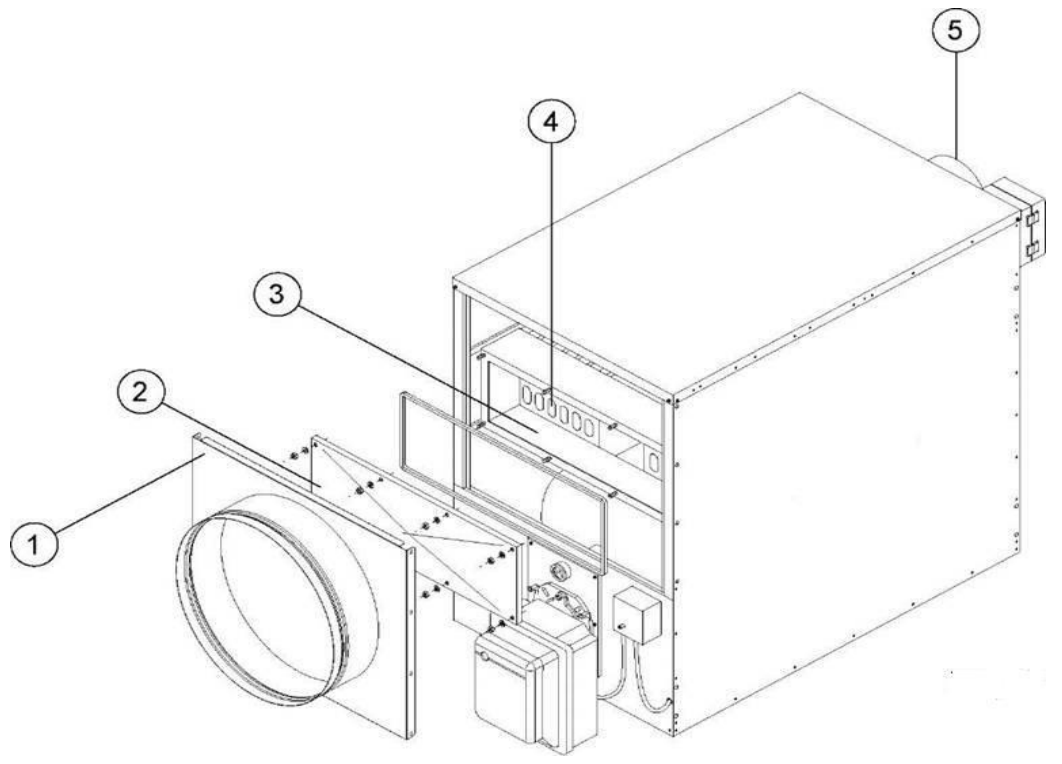

Fig (1): Forced air furnace includes the following:

(1) Removable air outlet, (2) Heat exchanger, (3) Front chamber,

(4) Oval heat exchanger tube, and (5) Chimney tube

\section{Gas burner}

The gas burner (model CIB UNI GAS, ITALY, S10, LP gas fuel) was functioned during the experimental work. The gas flow rate was between 6.9 and $12.7 \mathrm{~m}^{3} / \mathrm{h}$ as a minimum and maximum flow rates, respectively. The LP gas used during the heating period contented two components (Propane $20 \%$ and Butane $80 \%$ ). The calorific values (heating values) of the Propane and Butane components, respectively, are 42.8 and 45.6 $\mathrm{MJ} / \mathrm{kg}(11.889$ and $12.667 \mathrm{kWh} / \mathrm{kg})$.

\section{Perforated polyethylene duct}

A polyethylene duct $(240 \mu \mathrm{m}$ thick and $61 \mathrm{~cm}$ diameter $)$ of perforated hardboard is connected from one end to the forced air furnace and the other end was caped. It was mounted $2.0 \mathrm{~m}$ above the floor surface and run along the interior length of the house. The polyethylene duct was 
punched to provide circle holes of $5 \mathrm{~cm}$ diameter in order to distribute the warm air uniformly inside the broiler house with an aperture coefficient of 1.7 .

\section{Chicks}

A 5000 hybrid Cobb chicks of day-old with an average weight of $40 \mathrm{~g}$ was reared inside the broiler house during the experimental work.

\section{Measurements}

Two data-logger devices (16 channels, each) were functioned for measuring, collecting, and reading from different sensors (Therimstors) located at different positions inside the broiler house (each data-logger has a key-board and monitor). Fifteen sensors were evenly distributed at $25 \mathrm{~cm}$ above the floor to measure the indoor air temperatures within the birds zoon. Another fifteen sensors were also evenly distributed at 200 $\mathrm{cm}$ above the floor surface to measure the warm air temperatures just leaving the perforated polyethylene tube. One therimoster sensor was used to measure the outdoor air temperature. The means of 60 scans were recorded and stored in the memory every 5 minutes using the computer programs (Lap-Jack and profilap). The Lap-Jack program was employed to run the data-logger on the computer, and the profilap was functioned to correct the reading from analog to digital. The calibration of all sensors was completed successfully at the beginning of the experimental work.

\section{Methods:}

The experiment's data were collected in two stages through two production cycle. First cycle was used forced air heating system without perforated polyethylene tube. The second cycle was utilized the forced air heating system with perforated polyethylene duct.

\section{Thermal performance of forced air heating system}

\section{Heat energy supply}

The forced air heating system supplies heat energy inside the broiler housing. This heat energy supply can be calculated in terms of the mass flow rate of air (m) in $\mathrm{kg} / \mathrm{s}$, specific heat of inlet air $\left(\mathrm{C}_{\mathrm{p}}\right)$ in $\mathrm{J} / \mathrm{kg}{ }^{\circ} \mathrm{C}$, and the temperature difference between hot air $\left(\mathrm{T}_{\mathrm{o}}\right)$ and cold air $\left(\mathrm{T}_{\mathrm{i}}\right)$ in ${ }^{\circ} \mathrm{C}$, as follows:

$$
\mathrm{Q}_{\text {supply }}=\mathrm{m} \mathrm{C}_{\mathrm{p}}\left(\mathrm{T}_{\mathrm{o}}-\mathrm{T}_{\mathrm{i}}\right) / 1000 \quad \mathrm{kWh}
$$




\section{Specific heating power $\left(\mathrm{S}_{\mathrm{H}}\right)$}

The specific heating power required to heat $1 \mathrm{~m}^{3}$ of broiler house volume was calculated according to the heat energy supply $\left(\mathrm{Q}_{\text {supply }}\right)$ in $\mathrm{kWh}$ and the volume of house $\left(\mathrm{V}_{\mathrm{h}}\right)$ in $\mathrm{m}^{3}$, using the following equation:

$$
\mathrm{S}_{\mathrm{H}} \quad=\mathrm{Q}_{\text {supply }} / \mathrm{V}_{\mathrm{h}}, \quad \mathrm{kWh} / \mathrm{m}^{3}
$$

\section{Litter moisture content}

The litter was put in the oven at $105{ }^{\circ} \mathrm{C}$ for 24 hours. The moisture content of litter was computed in terms of moist weight $\left(W_{m}\right)$ in $\mathrm{kg}$, and dry weight $\left(W_{d}\right)$ in $\mathrm{kg}$ as follows:

$$
\text { MC. }(\%)=\frac{W_{m}-W_{d}}{W_{m}} \times 100, \quad \%
$$

\section{Feed conversion efficiency (F.C.E)}

Broilers feed conversion efficiency was calculated based on the broiler live-weight $\left(W_{b}\right)$ in $\mathrm{kg}$ and the broiler feed consumption $\left(\mathrm{F}_{\mathrm{C}}\right)$ in $\mathrm{kg}$, using the following formula:

$$
\mathrm{FCE}=\frac{\mathrm{W}_{\mathrm{b}}}{\mathrm{F}_{\mathrm{C}}} \times 100, \quad \%
$$

\section{RESULTS AND DISCUSSION}

\section{Effect of using perforated polyethylene duct on House temperature}

Providing and maintaining the indoor air temperature at desired level is crucial for chicks brooding from day-old to seven days. The normal pattern of brooding chicks is to warm them in a confined area at approximately $35^{\circ} \mathrm{C}$ at day-old and then subsequently reduce this $0.5^{\circ} \mathrm{C}$ daily till reaches to $22^{\circ} \mathrm{C}$. The temperature rise of the indoor air and its distribution within the house during the heating cycle is considered as an action indicative of the degree of heating process activity.

The weekly average indoor air temperatures; recommended, with and without perforated polyethylene tube and standard deviation with and without perforated tube are summarized and listed in Table (1). One of the criteria to judge the environmental control level is the standard deviation which used to assess the deviation of the average indoor air temperatures with and without perforated polyethylene tube from the recommended value. The standard deviation values (the positive square 
root of variance) revealed that, the lower levels were achieved when the forced air heating system used perforated polyethylene tube. Furthermore, the minimum value of standard deviation $\left(0.7^{\circ} \mathrm{C}\right)$ was observed with the forced air heating system connected to the perforated polyethylene tube at the end of living cycle. This observation means that, the modification system provided an indoor air temperature closest to that recommended by several researchers. Whereas, the highest value of standard deviation $\left(2.3^{\circ} \mathrm{C}\right)$ occurred during the first week of brooding when the forced air heating system was operated without perforated polyethylene tube. Therefore, using the perforated polyethylene tube provided and maintained optimal level for broiler chicks during both brooding and growing periods.

Table (1): Weekly average indoor air temperatures; recommended, with and without perforated polyethylene duct and the standard deviation during the experimental work.

\begin{tabular}{|c|c|c|c|c|c|}
\hline \multirow{2}{*}{$\begin{array}{c}\text { Living } \\
\text { cycle, } \\
\text { week }\end{array}$} & \multicolumn{2}{|c|}{ Indoor air temperature, ${ }^{\circ} \mathrm{C}$} & \multicolumn{2}{c|}{ Standard deviation } \\
\cline { 2 - 6 } & Recommended & $\begin{array}{c}\text { With } \\
\text { duct }\end{array}$ & $\begin{array}{c}\text { Without } \\
\text { duct }\end{array}$ & $\begin{array}{c}\text { With } \\
\text { duct }\end{array}$ & $\begin{array}{c}\text { Without } \\
\text { duct }\end{array}$ \\
\hline 1 & 33.0 & 31.2 & 29.7 & 1.3 & 2.3 \\
\hline 2 & 29.7 & 28.1 & 26.5 & 1.1 & 1.1 \\
\hline 3 & 27.5 & 26.2 & 23.5 & 0.9 & 1.8 \\
\hline 4 & 25.4 & 24.1 & 21.8 & 0.9 & 1.6 \\
\hline 5 & 24.0 & 23.0 & 21.3 & 0.7 & 1.1 \\
\hline
\end{tabular}

The recommended indoor air temperature, and indoor air temperatures with and without using the perforated polyethylene tube are plotted in Fig. (2). It evidently showed that the indoor air temperatures at a height of $25 \mathrm{~cm}$ above the floor surface along the broiler house when the forced air heating system was operated with and without perforated polyethylene tube during the two successive living cycles were varied from week to another according to the age of birds.

The indoor air temperatures decreased as the broiler age increased throughout the living cycle. Because of the brooding temperatures 
dependent upon the birds age especially in the two first weeks or on their body temperature, metabolic rate, ratio of average life weight to surface

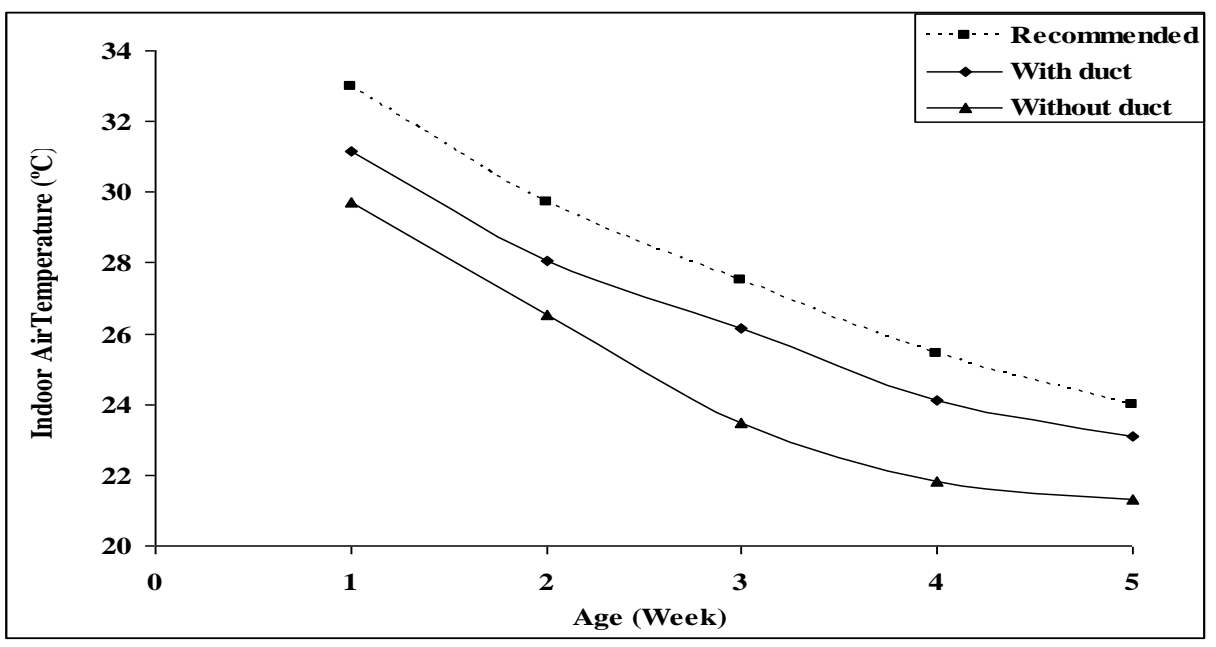

Fig. (2): Relationship between the indoor air temperatures (recommended, with and without perforated tube) and birds age.

area, insulation from feathering and thermoregulatory ability are all relatively low. It also revealed that, during the first week of age, the average indoor air temperature was $29.7^{\circ} \mathrm{C}$ and reduced to reach $21.3^{\circ} \mathrm{C}$ at the fifth week of age (last week) when using forced air heating without perforated polyethylene tube. While, connecting the perforated polyethylene tube to the forced air heating system (during the second living cycle) was $31.2^{\circ} \mathrm{C}$ at the first week and reduced to recognized $23^{\circ} \mathrm{C}$ at the last week of age. Therefore, the perforated tube uniformly distributed the indoor air temperature throughout the broiler house, resulting in increasing the average indoor air temperature and put the birds in comfort zone which enhanced the feed conversion efficiency.

The indoor air temperatures during the first and second living cycles had compared with the outdoor air temperatures as an important measure of the effectiveness of the environmental control system. The fluctuations of air temperatures surrounding the birds play an important role for their growth rate, development, and productivity. Fluctuation changes in indoor air temperature, caused by the forced air heating system either with or without perforated polyethylene tube, evidently observed inside 
the broiler house. A temperature gradient developed along the centerline of the broiler house and its value varied with time during each week of age. The best method to monitor the chicks comfort is to observe the bird's behaviour and regulate the indoor air temperature accordingly. For example, when the birds are distributed evenly across the house, it means that the indoor air temperature is at or around the optimal level. When the chicks are huddling together (even next to the side walls) and tends to sit in feeder pans, it means that, the birds are cool. Chicks that are hot will move away from the brooders and furnaces, will pant and stretch out on the litter in efforts to cool themselves.

\section{Influence of using perforated polyethylene duct on supplementary}

\section{heating addition}

The variation of heat energy addition to the broiler house during the two living cycles as a function of bird's age is plotted in Fig. (3). It evidently revealed that, during the first living cycle (the forced air heating system operated without polyethylene tube) the supplementary heat energy added to the broiler house at the first week was 197.892 MJ (54.97 kWh) which gradually decreased till reached the minimum value of $129.168 \mathrm{MJ}$ $(35.88 \mathrm{kWh})$ at the end of third week of age. It was increased after that until reached to $164.592 \mathrm{MJ}$ (45.72 $\mathrm{kWh}$ ) due to the brooded birds were translocated from a small partial area (brooding area) to the whole house brooding. During the remainder of the growth-out (two weeks) the heating system can not be delivered hot air to the end of house leaved the third part of house volume cold. Thus, the heating system was continuously operated to rise up the indoor air temperature in order to reach the recommended level. This means that, more addition of heat energy and gas consumption rate occurred. While, using the forced air heating system with perforated polyethylene tube for uniformly distributing the warm air through the broiler house (during the second cycle), the supplementary heat energy addition was decreased with increased the birds age. The supplementary heat energy addition was 194.4 MJ (54.0 kWh) at the first week of living cycle and reduced gradually till reached to the minimum value of $116.64 \mathrm{MJ}(32.4 \mathrm{kWh})$ at the fifth week of age, due to the perforated polyethylene tube 


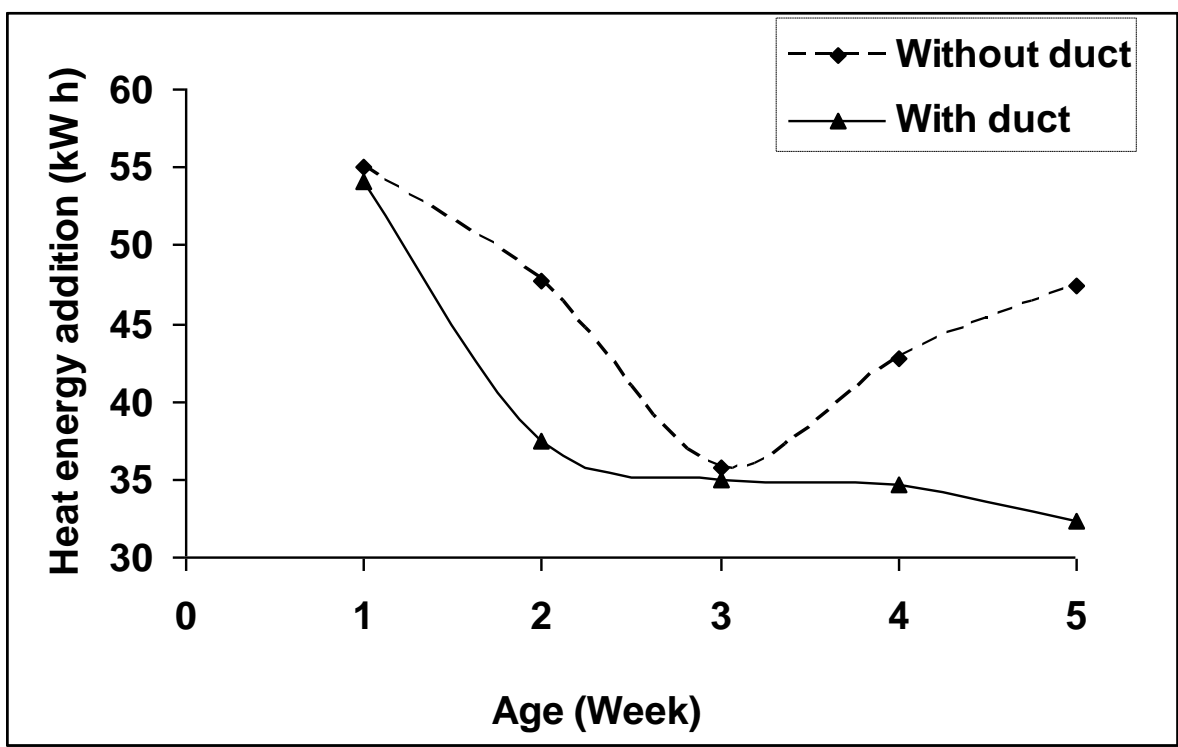

Fig. (3): Heat energy addition during the two living cycles (with and without perforated polyethylene tube) versus age of birds.

expelled the warm air downward into the birds zone. This heating process resulted in rise the house floor surface temperature and at the same time reduced the ceiling air temperature. Furthermore, this heating system delivered the warm air at the end of the house as well as the beginning and heating up the house fast. As a result of the previous reasons, the supplementary heat energy addition and the gas consumption were reduced.

\section{Effect of using perforated polyethylene tube on gas consumption}

The values of gas consumption during the two living cycles (using forced air heating system with and without perforated polyethylene tube) were plotted as a function of bird's age in Fig. (4). The obtained data showed that, the gas consumption during the heating process of the broiler house without perforated polyethylene tube was gradually reduced from $4.80 \mathrm{~kg} / \mathrm{hr}$ at the first week until reached the lower value of $2.38 \mathrm{~kg} / \mathrm{hr}$ at the third week of age. After that, the gas consumption increased again until it reached $2.75 \mathrm{~kg} / \mathrm{hr}$ at the fifth week of age. This occurred as a result of the brooded birds were translocated from a small partial area to the whole house brooding. In addition, the forced air heating system 
without perforated polyethylene tube was found to be insufficient to provide and maintain the indoor air temperature at the desired level for two basic reasons.

Firstly, forced air heating system expelled warm air in the centerline of the broiler house in order to heat the surrounding zone of birds that required along time to execute. However, the most heat energy used for warming the indoor air was moved upward by thermal buoyancy forces into the ceiling. This means that the temperature stratification occurred with warm air at the ceiling zone and the cold air at and around the floor surface (bird's zone). Secondly, the forced air heating system operated for a long time to provide a comfort zone for chicks due to the warm air translocated to underneath the ceiling, and the heating system kept adding heat energy to the house until the house floor zone became warm resulting in increasing the gas consumption.

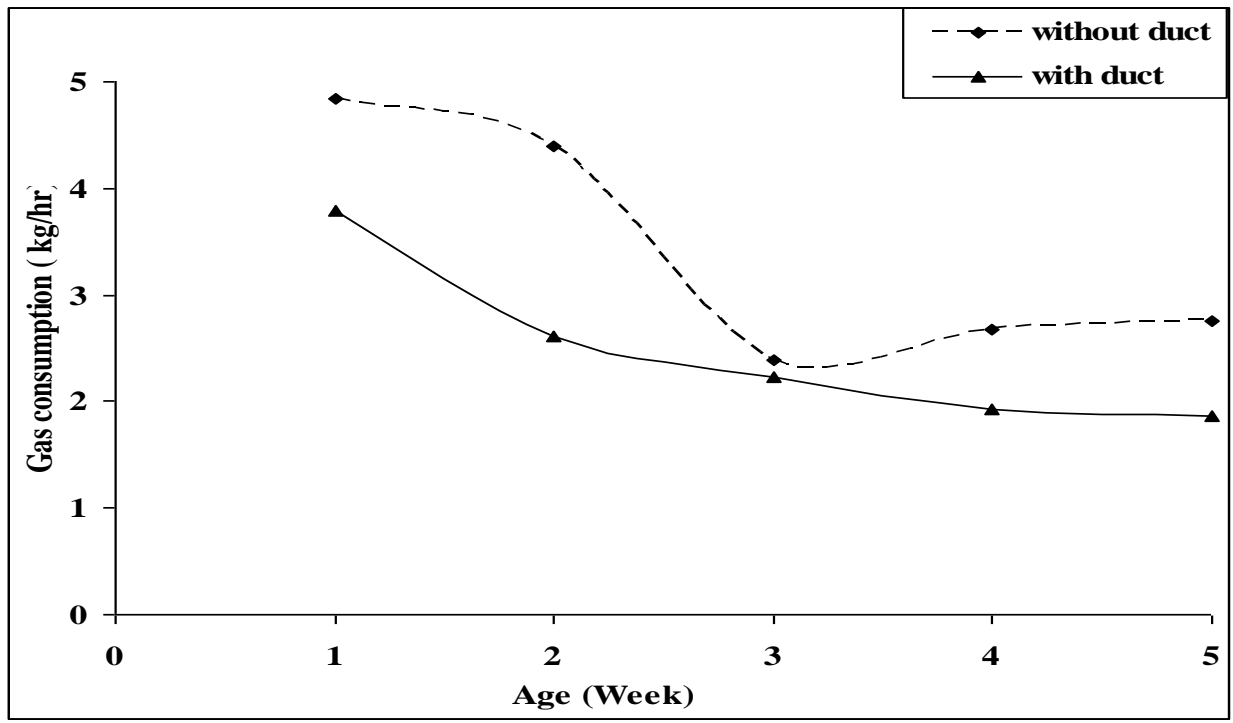

Fig. (4): Gas consumption during the heating process with and without perforated polyethylene tube.

Nevertheless, when the forced air heating system was connected to the perforated polyethylene tube for uniformly distributing the warm air inside the broiler house, the gas consumption reduced with increased the bird's age. The gas consumption during this living cycle was ranged between $\quad 3.79$ and $1.86 \mathrm{~kg} / \mathrm{hr}$. Because, the completed heating system 
expelled and directed the warm air downward to the floor zone and not into the ceiling which resulted in heating the floor in a short time and save fuel. Same trend was observed in Fig. (3) and Fig. (4), because the gas consumption is a function of supplementary heat energy addition.

\section{Specific heating power for one cubic meter of the house volume}

The relationship between the specific heating power for one cubic meter of house volume and the bird's age during the two living cycles is clarified in Fig. (5). Specific heating power depends mainly upon the heat energy addition to the broiler house during heating operation and the volume of that house. As, the bird's age increased, the specific heating power was decreased. Specific heating power during the first living cycle when the forced air heating system was used without perforated polyethylene tube was $0.0946 \mathrm{kWh} / \mathrm{m}^{3}$ at the first week of age and reduced gradually until reached $0.02625 \mathrm{kWh} / \mathrm{m}^{3}$. At the fourth week of age, after that, it increased again until reached $0.02915 \mathrm{kWh} / \mathrm{m}^{3}$ at the fifth week of age. This increasing can be almost completely attributed to the increasing of house volume and the heat energy addition to the broiler house accordingly at this period (the brooded birds were translocated from a small partial area to the whole house brooding).

Thereafter, during the second living cycle when the forced air heating system was connected to the perforated polyethylene tube, the specific heating power for one cubic meter of the house volume gradually decreased from $0.06638 \mathrm{kWh} / \mathrm{m}^{3}$ at the first week of age until reached to $0.0199 \mathrm{kWh} / \mathrm{m}^{3}$ at the end of living cycle. The previous obtained data revealed that, using perforated polyethylene tube resulted in reduced the specific heating power for one cubic meter of the house volume. Because, it was delivered the heat energy to the end of the house, increased the floor surface temperature, and decreased the total heat energy addition to the broiler house, in spite of the house volume increased particularly after the first three weeks of age.

\section{Effect of using perforated tube on air relative humidity and litter moisture content}

The ability of indoor air to hold moisture depends upon its temperature. The level of indoor air relative humidity influences the ability of the birds to cool them through panting and influences ammonia production. 


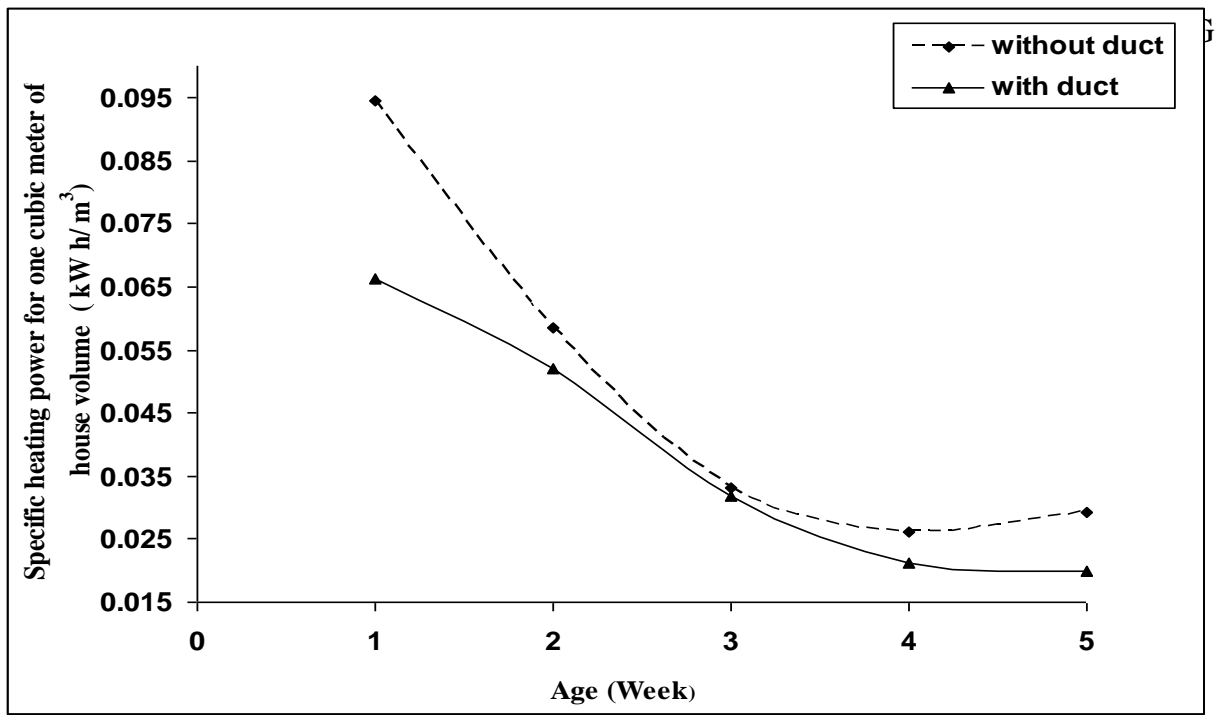

Fig. (5): Specific heating power during the two living cycles (with and without polyethylene perforated tube) versus age of birds.

Cyclic changes were observed in the air relative humidity, and the humidity ratio, which measured inside the broiler house. The cyclic variation in air relative humidity occurred at the peak of the heating cycle in the two living cycles. The indoor air relative humidity during the two living cycles decreased by $7.3 \%$ and $5.9 \%$ at the first week of each cycle, whereas at the end of the living cycles was increased by $9.5 \%$ and $8.1 \%$, respectively. The indoor air relative humidity increased at the end of the heating period due to the heat energy supplied during that time was insufficient to absorb more moisture from the indoor air.

Litter moisture content is an important factor that affects the broiler performance. Increase the litter moisture content, resulting in increasing ammonia gas emission. If litter was too dry, excessive dust will produce. The variation of litter moisture content as a function of age during the two living cycles was plotted in Fig. (6). It evidently showed that, the litter moisture content increased as the birds increased in age.

The litter moisture content was ranged between 27.7 to $41.5 \%$ when the forced air heating system was used without perforated polyethylene tube. Whereas, when using the perforated polyethylene tube with the forced air heating system, the litter moisture content was ranged between 17.8 and 
$32.8 \%$. In first living cycle, the litter moisture was too high because the air temperature underneath the ceiling was higher than that surrounding the birds, resulting in increasing the litter moisture content. While, using the perforated polyethylene tube with the forced air heating system, the warm air moved downward into the floor surface and consequently the zone of birds which resulted in evaporated the moisture from the litter and exhausted out by the ventilation system.

It is recommended that a low level of air relative humidity be maintaining during birds brooding and growing. Ammonia gas production mainly occurs due to the microbiological breakdown of fecal material in the litter. Increase air relative humidity improves environmental conditions for microbial growth in the litter. As the microbial population increases, more ammonia is generated from nitrogen sources found in bird's fecal material. Ammonia is a gas that has a negative impact on the bird's health and performance.

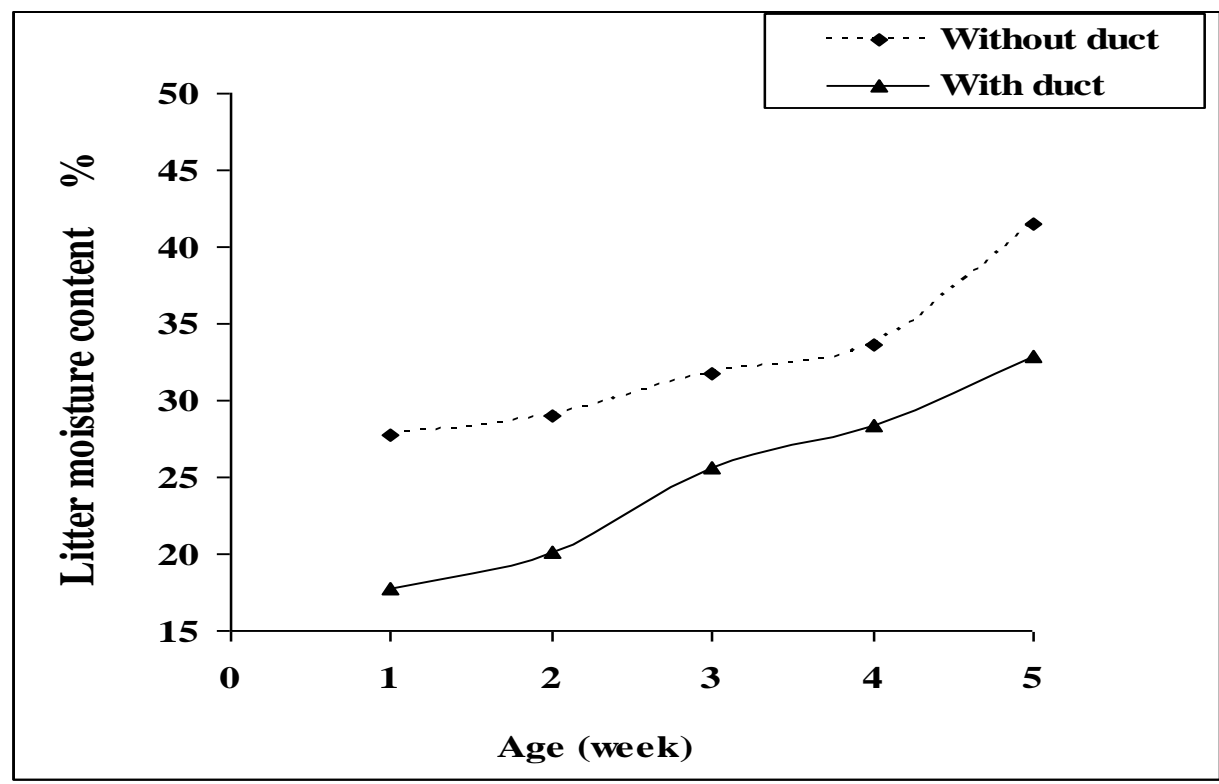

Fig. (6): The relationship between litter moisture content inside the broiler house and bird's age when using forced air heating system with and without perforated polyethylene tube. 


\section{Effect of using perforated duct on feed conversion efficiency}

Feed conversion efficiency has mainly been affected by temperature distribution inside the broiler house. One of the goals during the brooding and growing boiler chickens is to maintain chicks within their comfort zone. When birds are kept in environmental temperatures above or blow their comfort zone, more heat energy must be expended to maintain body temperature. This extra heat energy will ultimately be supplied by the feed consumed. Therefore, the energy from the feed will be used to maintain body temperature instead of growth and development resulting in poorer feed conversion. Thus, the environmental temperature plays a major role in determining the cost of producing one kilogram of meat.

The relationships between the feed conversion efficiency and the broiler age during the two successive living cycles (when the forced air heating system inside the broiler house with and without perforated polyethylene tube are plotted in Fig. (7). Feed conversion efficiency was found to be decreased as the age of birds increased. Therefore, the feed conversion efficiency was $98.56 \%$ at the first week of age and reached to $60.40 \%$ at the fifth week of age during the first living cycle. Whereas, the feed conversion efficiency during the second living cycle was $99.60 \%$ at the first week of age and reached to $62.2 \%$ at the fifth week of age. The obtained results showed that, the feed conversion efficiency slightly increased when using perforated polyethylene tube for uniformly distributing warm air inside the broiler house. During the first living cycle the warm air expelled out from the heater and raised up into the house ceiling zone instead of the bird's zone resulting in birds huddling together in groups and most do not seek out feed or water which adversely affected the feed conversion efficiency. Thereafter, during the second living cycle when the forced air heating system was connected to the perforated polyethylene tube, the mean temperature in the bird's zone was closest to the desired level recommended for the broiler chicken. Thus, the birds were more comfortable which enhanced and increased the feed conversion efficiency. 


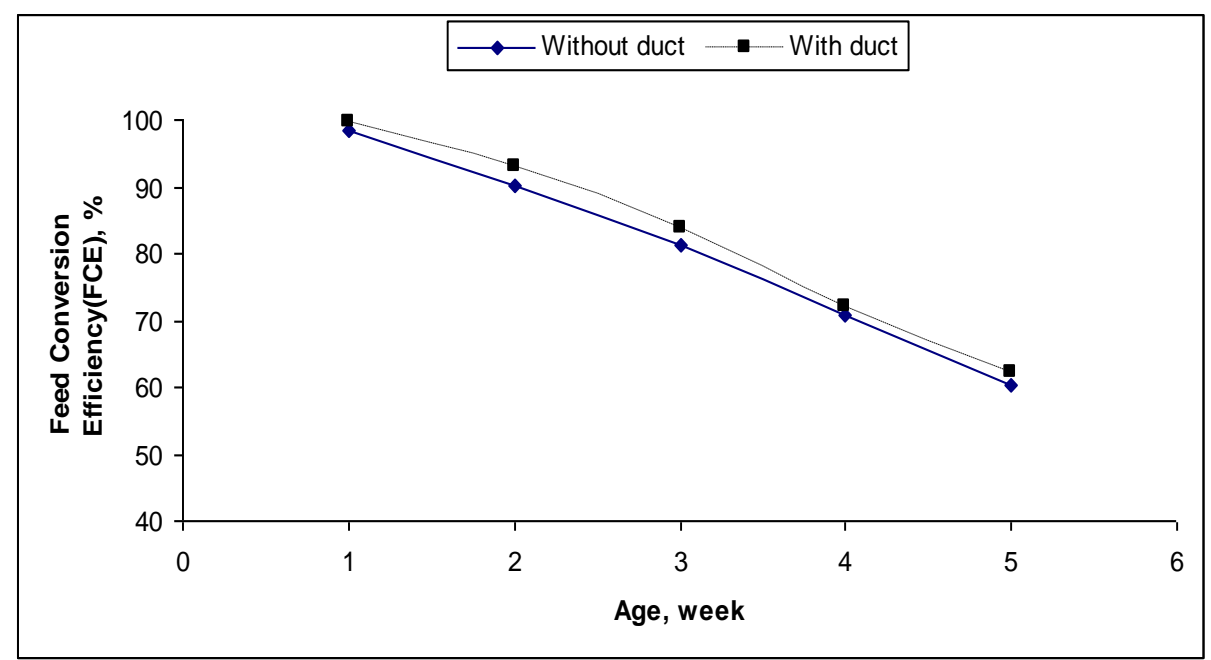

Fig. (7): Feed conversion efficiency with and without duct

\section{CONCLUSION}

The main results of the present research can be summarized as follows:

1- Using perforated polyethylene tube for heat distribution increases the indoor air temperature to be at and around the desired level.

2- Using perforated tube for uniformly distributing the warm air inside the broiler house, led to reduce the gas consumption by $27.07 \%$.

3- Using forced air heating system with perforated tube reduced the supplementary heating by $15.35 \%$

4- Using perforated tube led to decrease the average litter moisture content by $20.83 \%$ at the end of life cycle.

5- Using perforated duct for heat distribution help in increasing feed conversion efficiency by $3 \%$.

6- Using perforated polyethylene tube help in increasing the broilers body weight by $10.52 \%$

\section{REFERENCES}

Czarick, M. and B. D. Fairchild (2003) "1/15 hp circulation fans" Poultry Housing Tips, University of Georgia, Cooperative Extension Service, November, 15 (10) 
Czarick, M. and B. D. Fairchild (2005) "Temperature stratification during brooding" Poultry Housing Tips, University of Georgia, Cooperative Extension Service, February, 17 (2)

Donald, J(2003) Principles of successful wintertime broiler house ventilation Avia Tech 1(4). Aviagen, Huntsville.

Egyptian ministry of Agriculture (2009) "Economical Affaires Sector" Agriculture statistic bulletin

Fairchild, B. D. (2009) "Environmental factors to control when brooding chicks" University of Georgia, Cooperative Extension service, Colleges of Agriculture and Environmental sciences, March, Bulletin 1287: 1-6.

Fairchild, B. D. (2012) "Environmental factors to control when brooding chicks" University of Georgia, Cooperative Extension service, Colleges of Agriculture and Environmental sciences, March, Bulletin 1287: 26-34.

Ghoname, S. A. (2012) "Thermal performance analysis for forced air heating system in broiler housing" M.Sc. Thesis, Department of Agricultural Mechanization, Faculty of Agriculture, Tanta University, Egypt

Lacy, M. P. (2002) "Broiler management" In: Bell, D. B. and W. D. Weaver, eds. Commercial Chicken Meat and Egg Production, 5th ed, pp 829-868

Mitchell M.A. and P.J. Kettlewell, (1998) "Physiological stress and welfare of broiler chickens in transit: solutions not problems" Poultry Science, 77: 1803- 1814 


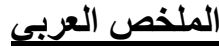

\section{تقليل متطلبات الطاقة اللازمة لتدفئة مساكن دجاج اللحم

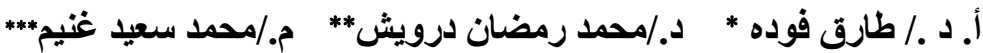

أجريت هذه الدر اسة فى مسكن لاجاج التسمين فى قريـة بابـل مركز تـلا بمحافظة المنوفية حيث

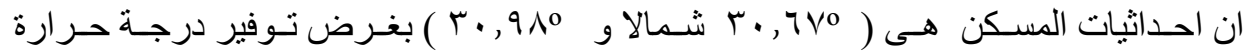

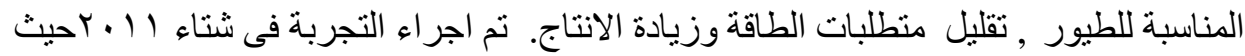
تمت التجربة خلال دورتين متتاليتين باستخدام هجين( كاب) عر يوم واحد. الدورة الاولى تمت الته

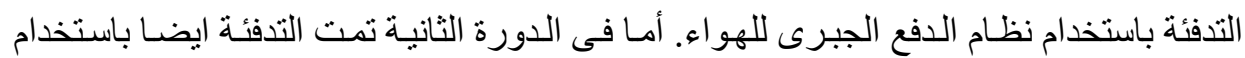

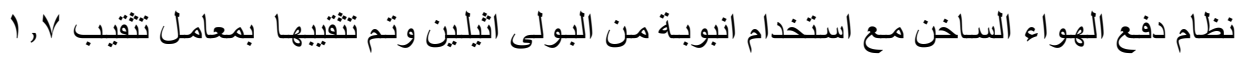

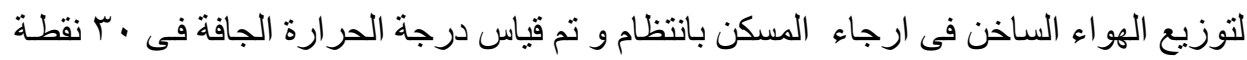

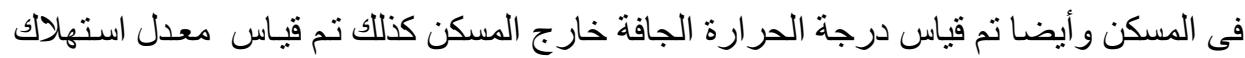
الوقود , كمية الحرارة الازمة للتدفئة الطيور , رطوبة الفرشة و كفاءة التحويل الغذائى الى لحم وكانت النتائج النتحصل عليها هـى كتالى :

عند استخدام نظـام التدفئة مـع وجود انبوبـة مثنبـة من الايثيلين ارتفع متوسط درجـات الحرارة

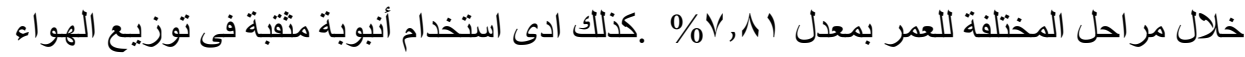

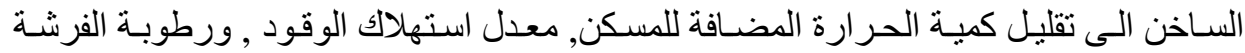

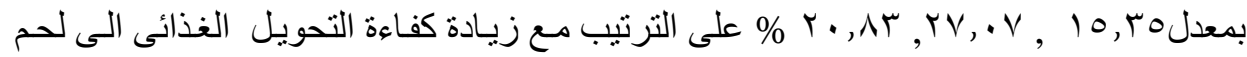
بمعدلr\%

\footnotetext{
* أستاذ الهندسة الزراعية_ قسم الهندسة الزراعية ـ كلية الزراعة ـ جامعة طنطا. *مدرس- قسم الهندسة الزراعية ـ كلية الزراعة ـ جامعة طنطا.

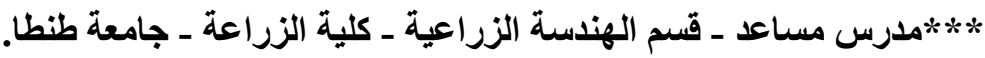

